\title{
16
}

\section{Tracks and shadows: Some social effects of the 1938 Frobenius Expedition to the north-west Kimberley ${ }^{1}$}

\author{
Anthony Redmond
}

In 1938, Andreas Lommel, newly graduated in anthropology and archaeology from the Frobenius Institute in Frankfurt, along with his colleagues Helmut Petri and Agnes Schulz and an Australian postgraduate student in psychology, Patrick Pentony, spent several months conducting fieldwork in and around Munja Government Station on Walcott Inlet in the north-west Kimberley region of Western Australia.

When I arrived in the Kimberley 56 years later, intent on studying jurnba (a Kimberley Aboriginal public song genre), together with its performers and composers, Lommel's German-language monograph Die Unambal, ein Stamm in Nordwest-Australien (1952) was an important source for approaching this subject. A newly published Oceania article compiled by Alan Rumsey as a collaboration between Lommel and senior Ngarinyin man David Mowaljarlai (Lommel and Mowaljarlai 1994), had already whetted my appetite for exploring the song texts composed by Alan Balbungu, which had been partially transcribed in Lommel's monograph.

1 This chapter is dedicated to the memory of Frank Zandvoort: adventurer, linguist, farmer and unforgettable friend. 
Alan and Francesca Merlan had also recorded local people singing a number of these texts during their fieldwork in Ngarinyin country in 1993. These teachers and colleagues subsequently introduced me to Mowaljarlai during one of his visits to Sydney to work on their Ngarinyinlanguage texts, and a plan was put in place for me to begin fieldwork with Ngarinyin people in the following year.

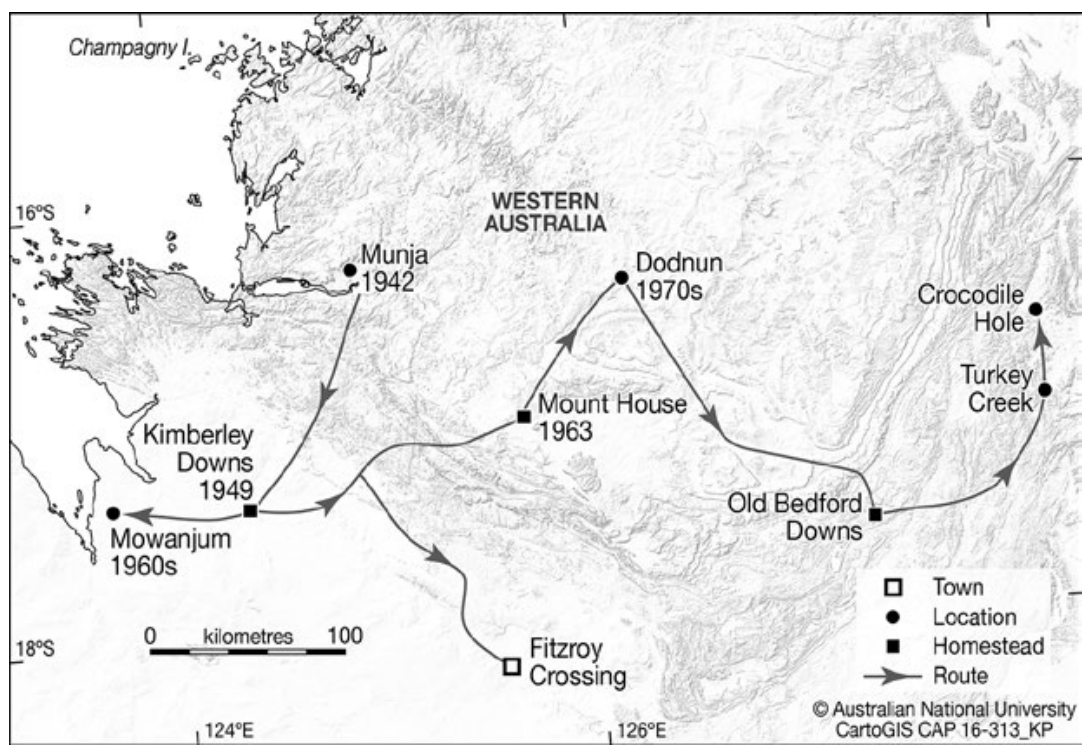

Map 16.1 The movement of the song cycle across the Kimberley.

Source: CartoGIS, The Australian National University.

One of my first points of call in July 1994 was to visit senior Ngarinyin man Laurie Gowanulli to talk about the Balbungu songs. While Mowaljarlai was a boy of just 10 in 1938, Gowanulli was already a young man of 20 or so when he first met Lommel during the Frobenius Institute group's visit to Munja.

Laurie was more than happy, as it turned out, to sit with me and my good friend, Frank Zaandvoort, who had recently completed a translation of Lommel's German-language monograph for me to work from. Laurie also agreed to sing and record more of the Balbungu song corpus with us and, in between those recordings, he reminisced at length about those pre-World War II times in Munja. 


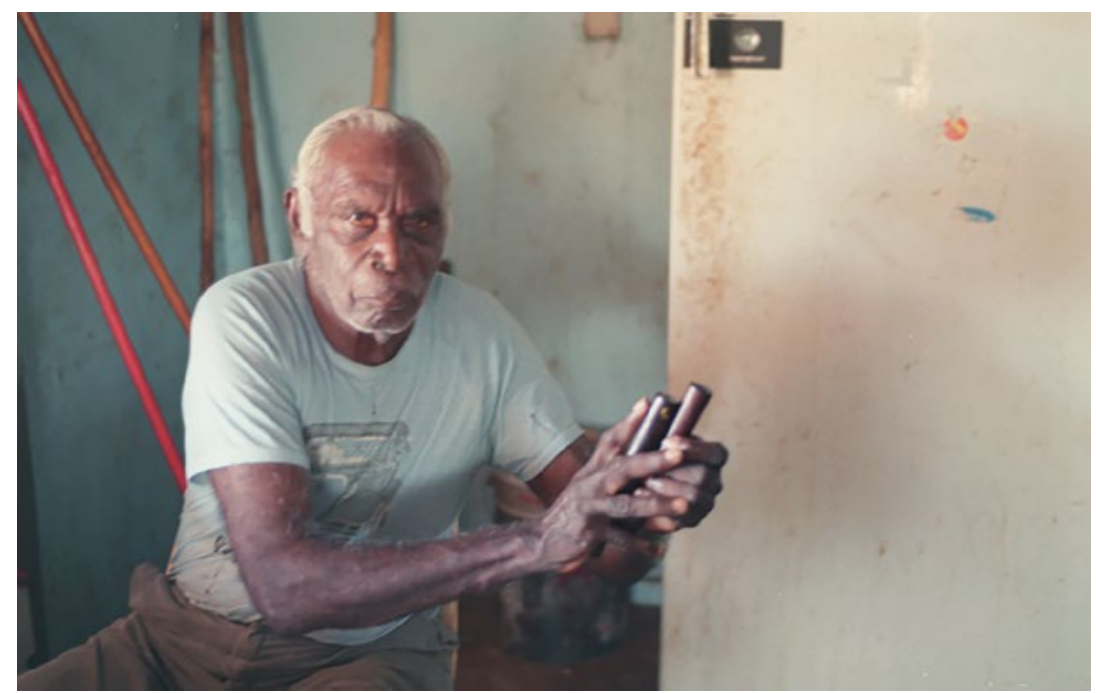

Plate 16.1 Laurie Gowanulli at Mowanjum, July 1994.

Source: Anthony Redmond personal collection.

By the time we had made our way through recording as many of the remaining Balbungu songs as Gowanulli (Gowan) could recall, I was very much under the spell of that charming gentleman's songs and stories and determined to follow up the possible implications of the songs themselves, the shamanic process involved in dreaming them and the ways in which they were used and distributed across that social world.

Gowanulli's reflections on Lommel's 1938 visit to Munja provide some interesting insights into what kind of sense Aboriginal people living in those settlements were making of the presence of these particular Europeans, who were so unusually interested in their sociocultural world, and how he and his countrymen contextualised this interest in them within the rapidly unfolding events that would soon draw the entire region on to a wartime footing.

In the first instance, Gowan described how he and his countrymen had generously taken care of Lommel and the other members of the Frobenius Expedition despite an uneasiness about the exact nature of these visitors' motivations for collecting examples of sacred ceremonial boards and making hand-drawn copies of the wanjina cave paintings to be subsequently shipped back to Europe: 
Mark 'em [draw them] people. ${ }^{2}$ I can't see how he drawing all the old people and all that, Wanjina too.

They [his countrymen] take 'em out, stockman boy took 'em up there in that cave place and deliver 'em there, one boy look after 'em, right, they all getting all that cave drawing and mark 'em all that exactly like that thing that was in the cave too, in that paper they bin put it. They all took 'em right back there but we never got answer from all that time. We don't know what they took'em for. That Germany is a long way from Australia.

When I asked Gowan what he and his friends might have received in return for their investments of care, knowledge and time in their German visitors, he was emphatic that there had been little in the way of reciprocity (only lollies and tobacco), but he quickly located this in its particular historical context. In those days, he said, his people typically responded to requests from whitefella strangers much as they would to a request from an Aboriginal person coming from far afield and therefore in need of assistance and support because they were marooned in an unfamiliar social world. That was, he maintained, a very different situation to nowadays when Aboriginal people had become much more wary about requests for cultural, and especially ritual, knowledge and voiced their opinions and expectations much more stridently:

Nothing. No, we don't know what we give them for, we never had that thought, you know, we never thought about it. Not like now, everybody expecting, 'What for this, what for that, what you want this for?'

All that thing only coming out today. My time, when I bin grow, we only used do work, friend coming from there, long way we give what he ask for, he welcome, we give 'em anything, he can learn, something, well like the Germany mob they come there, we be good to them, give us everything what we needed like lolly and thing, and we give them thing and gone back home.

2 Agnes Schulz was by all accounts a very proficient portraitist and drew a number of portraits of people living at Munja, including Gowanulli's close friend, the late Paddy Wama. 
To emphasise the cooperative and friendly approach his people had taken in those early days with white strangers, and Germans in particular, Gowan compared his countrymen's open-handed assistance to Lommel's party with the lifesaving kindness kinsmen from Drysdale River Mission had provided in finding two lost German airmen who had crash-landed their aircraft on the mudflats of the north-west coast in $1932:^{3}$

Like that two bloke there, I don't know about two, when German travel back with the plane and when they crash somewhere in Wyndham, they crash there and Aboriginal people bin grab them, mind 'em-we see 'im in movie they make film all the time- the blackfellow look after them two German, they was still all right, fly 'em to Broome, nothing wrong with the people.

But like this now what this one we give 'em [referring to Balbungu's songs], he welcome, good, old man was all right, old man he was the composer, he was the boss of the corroboree. We been pleased when anybody come up listen, recording, not this sort of one [pointing to my digital tape recorder], different one, long like that [early wax cylinder recording apparatus], like this he put that thing machine through from there and make him sing that he pick up like this cassette and he get a recording in there now. But that was old time, I never see that one now.

In these particular discussions, Gowan barely acknowledged the prevailing colonial context in which white managers infamously exerted an intermittent and often unpredictably violent control over the many Ngarinyin, Wunambal and Worrorra people who were by then living part of the year in and around Munja Government Station. In his view, although subjected to an onerous seasonal work regime in Munja's peanut oil plantations, the most senior Aboriginal men at least continued to exercise a high degree of personal autonomy and mobility. The implication was that the assistance offered to these European strangers was largely on his countrymen's own initiative and was derived from their traditional ethic of kin-based generosity rather than being coerced by mission managers:

3 Hans Bertram and Adolf Klausmann were flying the Junkers W33 seaplane Atlantis from Cologne, Germany, on a goodwill mission to Australia for the aircraft maker, Junkers, when they ran into a severe storm between Timor and Darwin. Flying during the night of 15 May 1932, they became lost in thick cloud. Eventually, at dawn, running short of fuel, they spotted the coast and landed in a sheltered bay. After a sleep and a think, they decided to use their remaining fuel to fly further down the coast, closer to where they believed the nearest town was located. In fact, they moved further away from civilisation, finally landing near Rocky Island, about 170 kilometres northwest of Wyndham. See: simplyaustralia.net/article-strangers2.html. 
Well, like the German mob, we just come friendly, well we know nothing. He give us what he give us, only give 'em lolly, he might get tobacco, he give 'em, not tea and sugar flour, no, only what he got it, he give them now lolly and that sort of thing, old people there, they give them whole lot and the old people go easy and give them.

Reflecting on that possibly naive and open-handed attitude to strangers, Gowanulli believed that, in recent times, his countrymen had developed a more knowing and self-protective diffidence in such dealings as they had become more conscious of the ways in which their cultural resources carried potential value in their negotiations with Europeans:

You know if people come to ask to know everything, to understand, if people come they be surprised, what you, maybe you say, ask me, 'I want that.' 'What for?' 'Oh for so and so.' Might be you want me to get that thing. Well everybody find that very hard, difficult to know this time. Taking away country thing, you know ... Yeah little bit changed this time. They want to come now well it little bit very hard for anyone coming here to ask what he want them for and all that. Everybody learn about this government business, 'What for he want, what he come for, what you gonna do with all that.'

Like all this people now, this $\mathrm{KLC}^{4}$ mob and all this, everybody all argue one another. I don't know nothing me because I'm don't interesting, you know.

After being in the field for some three months or so working with Gowanulli and his countrymen, Lommel and his companions, being mostly German nationals, had to make a hasty departure from Australia as the war threatened in Europe.

This 'second Germany war' remained rather remote for Kimberley Aboriginal people, whose knowledge of Anglo-Australian-German geopolitics was largely conditioned by their interactions with World War I veterans who had subsequently become stockmen, prospectors and missionaries in the Kimberley. These relationships ranged in emotional tone from the relatively respectful and friendly relationships established with returned Anglo-Scottish veterans, such as the supervisor of the Kunmunya Presbyterian Mission, 'Mr Love' (Reverend W. R. B. Love), and Dave Rust, the manager at Karunjie Station, to their interactions with

4 Gowan and some of his countrymen were, at the time of this interview, involved in a longstanding dispute with the regional Aboriginal political body, the Kimberley Land Council (KLC), in regard to the perceived infringement of Ngarinyin people's local autonomy in mounting litigation over land claims. 
more violent, and sometimes positively deranged, veterans of the Light Horse Brigade, such as Scotty Saddler and Scotty Salmond (Redmond and Skyring 2010).

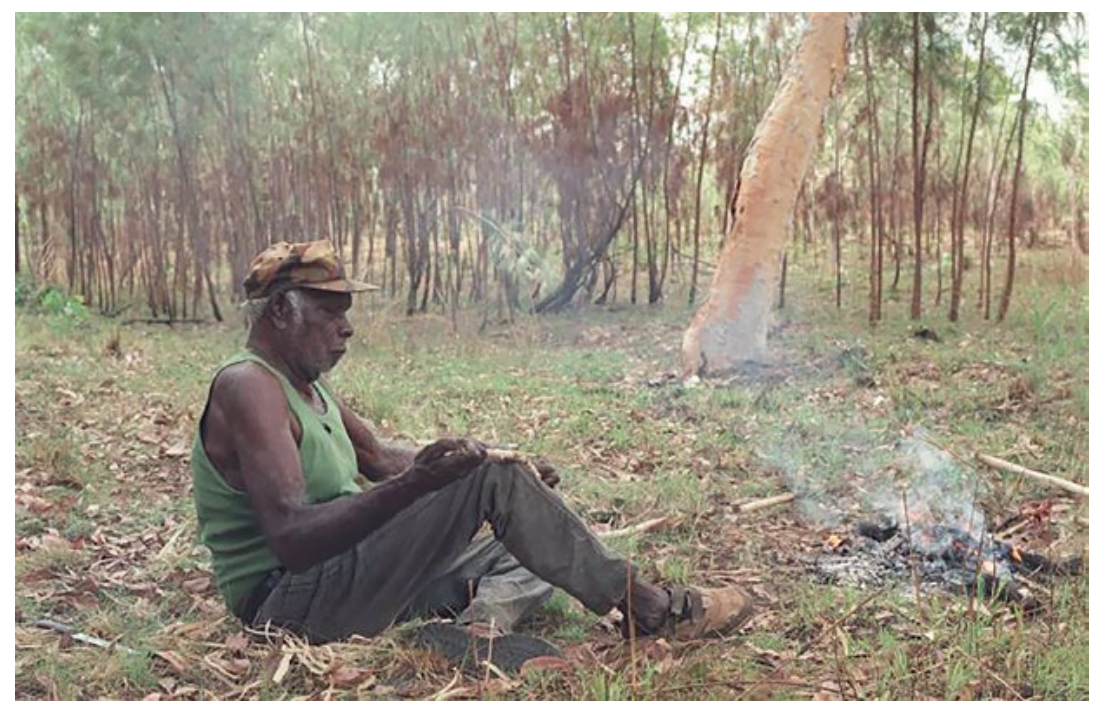

Plate 16.2 Gowanulli travelling in Garnlingarri country, 1996.

Source: Anthony Redmond personal collection.

Gowanulli suggested that the 'Germany war' may have been in some sense linked to the mystifying European interest in retracing wanjina images from the northern Kimberley cave galleries and the collection of ritual artefacts from ceremonial performances. He contrasted this link between the war and the German interest in collecting magico-material artefacts of Aboriginal ritual life with the much more pragmatic interests leading to the 'Japani war'. In his view, this latter war was driven simply by the Japanese appetite for mineral resources, particularly those located in his Worrorra countrymen's territory on Koolan and Cockatoo islands off the west Kimberley coast:

Now we thought about this little way ... Hey, German must be making war for this drawing business Australia, but it was Japanese mob start war second time, after Germany. German mob come here just to get 'em drawing and he took 'em back to Germany but it was Japanese was start the war-only for that goldmine, iron, there in Cockatoo [Island]. That wasn't long war, only short war and they finish. 
Given Gowanulli's proposal that his countrymen's interactions with the visiting Frobenius Institute personnel were largely modelled on the ways in which they would have interacted with an Aboriginal relative stranger, at least part of the significance attributed to the German anthropologists' retracing of the wanjina cave art imagery might be illuminated by referring back to those local practices and beliefs.

\section{Tracing the wanjina}

Wanjina become incarnated in the living persons who identify with their wanjina by referring to it as 'I' or 'me' when narrating stories of events occurring in the larlan ('ancestral past'). Gowanulli, who belonged to the Brrejalngga clan, would narrate the story of how his wanjina was bitten on the upper arm by Bamali, a king brown snake in the larlan, by pointing to his own right arm and talking of the actual site where 'king brown bite 'em me'. One of Gowanulli's personal names, Nyajngo, derived from this biting action in the larlan. In a similar vein, another (now recently deceased) senior man, Neowarra, told me how:

my father carried that Gayun.gu [Mt Barnett Range] on his shoulder right up to Manggurarri [near Doongan Station]. When he was carrying that ranges, that's larlan di, my grandfather found him there at Manggurarrithat's why my father got that name Manunggu, it's the same meaning as Gayunggu.

Here Neowarra was referring to his father as wanjina. The emphasis on the shoulders as the place on the body where country is carried reflects the fact that it is the father/son relationship that is figured in muscle twitchings at this bodily site, and also the place where child-spirit essences are often seen to 'sit'. Neowarra took his personal name from the black rocks (nyawarra) in the Munja area, where 'my father found my spirit when he was walking around that time'. Similarly, one of his classificatory sons takes his name from a female ancestral kangaroo, Nyenowarr, which gave birth to his actual father at Warr muj mulimuli in the Caroline Ranges. Thus, wanjina simultaneously carry the country and the clansmen who will care for it, carrying responsibility for that country across the generations. This concept of 'carrying' country and the burden of transmitting the law to the younger generations is a major concern of senior people. ${ }^{5}$

5 A similar image has been described by Myers (1980: 199) as focal among the Pintupi, for whom responsibilities of sacred knowledge are associated 'with phrases denoting some sort of physical object and indicating a weight burden, or responsibility for the "holder". 
The maintenance of a fully vitalised natural and social world is something that senior Ngarinyin people say is achieved through their regular presence on country and conducting the appropriate ceremonial rites. The presence of the 'right people' for specific country is in itself believed to 'brighten' country and to release the inherent fecundity of its ancestral powers. This condition of abundant vitality is known as yayiyurru ('everything standing up in a bunch'). Senior people say the country recognises its own by ngalug ('odour') and the familiar sounds of such people's voices.

Conversely, the absence of the right people from country will cause diminished supplies of native fauna and flora, waterholes and rivers will become dry with the onset of a 'melancholy' or 'depression' in the country itself, in the same way that a person who is lonely or 'sorrowing' (marari) for a particular place might experience homesickness. Both the wanjina imagery and the country are said to become faint and lacklustre through the absence of this regular human contact. My Ngarinyin colleagues maintain that what were once extremely fertile breeding grounds for waterfowl at Munja, for instance, have become very depleted during a recent period of sporadic occupation.

One of the ways in which an ecological balance can be maintained is through the human attention given to maintaining the 'brightness' of the wanjina paintings in each clan country. People were said to have a ritual obligation to country where they have a strong connection deriving from one of a number of potential links. Mature persons other than clan members (but still belonging to the wanjina sociocultural domain) could be invited to repaint the wanjina images in another person's clan country. Those with a more direct responsibility for the sites would then give these painters gifts (ngurli) of kangaroo meat or sugarbag.

These wanjina images are not thought of as the artistic work of the ancestors of present-day people, but rather as the bodily imprint of autochthonous ancestors, whose images have merely been maintained - 'kept bright' - by a ritual repainting. This repainting — 'touch 'em meself' in Kriol—with its profound ecological and social consequences, is a self-generative action that humans should duplicate, augment and give an enhanced visibility to (Mowaljarlai and Malnic 1993; Mowaljarlai and Rumsey 1992; Rumsey and Mowaljarlai 1994; Crawford 1968; Blundell and Layton 1978; Blundell, Woolagoodja et al. 2005). Neowarra explained that the 
repainting process is initially activated by the emanations of wet season moisture from the rocky outcrops in which the paintings are located and that human agents then complete this revivification:

In Winjin ['wet season'] time when that wilmi ['mist'] come out from the stone in early morning, jurri we call it, the 'smoke' goes into the paint and renews it and it's just like it paint up again so we can go always go back and renew it.

Lommel (1996: 17) found similar expressions among the Wunambal in 1938 and noted that people had told him how the wanjina at Merrinbini:

still becomes ever stronger with each progressive completion of his image. When he painted himself in the Dreaming for the first time he shouted to his brothers and sisters exultantly;-—look at me, how I paint myself, look here how my hands get stronger, how the picture takes shape.ll He became stronger and stronger and there were tremendous rains. (Lommel 1996: 43)

The German anthropologists' persistent interest in the wanjina imagery was remarkable enough to local people that when Lommel returned in 1955 with his wife, Katerina, to conduct large-scale retracings of the wanjina images at the major sites of Wanalirri, Anggurrman and Ngalanggunda, local people living at nearby Gibb River Station named the well where the Lommels had established their base camp 'Lommel Yard'. High ritual status and associated ritual dangers attach to these particular ceremonial sites because it was from here that all of the region's wanjina had once gathered to wreak war and send world-destructive floods against humanity in revenge for humans' transgressive insults against them. During my fieldwork, many senior clanspeople for these sites refused to go anywhere near them for this reason:

Yes. Yes, what's that- that crocodile been come from Box Hole, Wanalirri. And from there he been come from Lommel Yard. And that two crocodile meet now. But nobody won't go in that place-my place. I don't know how come. He doesn't—nobody won't go in that place, nothing. Can't do it. Yes. Everybody. All the Gibb River boys and Gibb girls, they don't go in —in that place, you know. Only just fishing, ride around. No, tourists wouldn't go in. I don't know. He don't go. Only in the Wanalirri they can go.

Them two crocodile been-come from where he been drown them. I don't know ... From there, he [wanjina] been come to-what that place? Box Hole [Wanalirri]. That drawing? And another one going to stop there, and these two [wanjina] they been walk away, go in that Lommel Yard. Two fella been stop there, find that cave, you know. Two fella been lay 
down there. Wife and husband. From there, he been cross over, you know, go in that place there, low down to Wire Yard. I don't know what that place. I forget now. Diyan.gin. Yes. He been go right up there ... and because he been find that cave, you know, he been stop there. One place he been stop. He never move anywhere no more. Three altogether they been go there. But I don't know what-when they feed them kangaroo, he go straight for that cave, but I won't go in that place. He's danger again. Big [rain]. He make big [flood] ... everywhere. (Maudie White quoted in Federal Court of Australia 2001: 4883-4)

Close local attention, then, was being paid to Lommel and his party's intimate interactions with, and uncannily accurate retracing of, the wanjina images. Similarly close attention was being paid to the German anthropologists' collection and transportation of ceremonial artefacts just prior to the outbreak of the war.

Over the next three years, with the entry of Japan into World War II, the Kimberley region itself would become an intensively militarised zone. Airbases were established near Liveringa in the Fitzroy Valley and just outside the township of Derby. Australian and American military personnel were deployed across the region, including the servicemen involved in the construction of the US Navy's radar base at Champagny Island on the north-west coast, not far from the Presbyterian mission at Kunmunya. The town of Broome was bombed and strafed by Japanese fighter planes, killing scores of Dutch refugees from Java who had just landed in seaplanes on Broome's Roebuck Bay. The Benedictine mission at Kalumburu, on the far north coast, was bombed in 1943, killing five of the Aboriginal residents as well as the mission director. ${ }^{6} \mathrm{~A}$ widespread fear of being shot by invading Japanese soldiers—something that then featured strongly in regional Aboriginal rumour mills_compelled many bush-dwelling Aborigines closer to European settlements, very much in accordance with wartime government policy (Crawford 2001: 245).

By 1942, at Munja Station, as throughout the rest of the northern Kimberley, the rumours of war had become a reality. For the majority of local people, this 'Japani war' would provide their first lived experience of the physical extent of modern military power as well as accelerating the integration of the more remote regions of northern Australia into the centralising bureaucracy of the modern war machine.

6 This was despite the precautions taken by the Benedictines in moving the mission further away from an airbase that had been established against their wishes in the vicinity of the original mission. 
The West Australian state supply ship Koolinda and her 'classificatory sister ship', MV Koolama, ${ }^{7}$ would both be memorialised in local Aboriginal song imagery following the sinking of the Koolama off the Kimberley coast by Japanese planes within two years of the Lommels' departure from the Kimberley.

The destructive drama of these sinking ships almost instantly provided the inspiration for a set of newly dreamt songs for Gowanulli's contemporaries. Gowanulli surmised that it must have been MV Koolinda that had, in fact, carried away the ceremonial paraphernalia collected by Lommel and Petri following their 1938 visit:

They [his countrymen] took 'em [the anthropologists] with the camel. They go right round, pick 'em up with the camel and take 'em right round, show 'em everyway, they give them all this corroboree thing now, material, long long one [a reference to the secret-sacred Kurangara boards, photos of which were later featured in Lommel's monograph], ${ }^{8}$ took 'em to right to Kalumburu, Wyndham, they get boat from there, ship steamer, might be Koolinda. Took them to England, from England then get another boat—might be another boat. German never come back again. That Dr Elkin mob (where he belong, Perth eh, round Sydney?). Same time he was round with that mob too. But his own, he running himself, this German mob self again. Dr Elkin mob was in Kunmunya and this mob Germans was in Munja.

7 'In 1941, the state ship Koolinda was travelling north when it encountered two lifeboats carrying 31 German sailors. The Germans were rescued at gunpoint and the few able to speak English explained that their German raider had sunk during a battle with an Allied cruiser which had also sunk. The cruiser was the Royal Australian Navy's HMAS Sydney which was lost with all 645 of its crew. The loss of the Sydney spurred significant mystery and controversy until the wreckage was found in 2008. In 1942, the state ship Koolama sunk alongside the Wyndham jetty after it was bombed by Japanese planes. The Koolama had been heading along the Kimberley coast from Darwin when long-range Japanese bombers scored two direct hits. Captain Jack Eggleston managed to beach the Koolama on the Kimberley coast where passengers were able to escape the ship and ultimately to be rescued with assistance from the Kalumburu Mission' (Collins and Smale 2014).

8 This was against the express wishes of Ngarinyin people who, with my assistance, had explicitly written to Lommel asking him to not include these photos of secret-sacred rituals in the English edition of his monograph. 
Another travelling west Kimberley ceremony, Juluru, similarly employs scenes from the sinking of the SS Koombana during a cyclone in 1912.' Until its loss with all hands on board, the Koombana, like the other state supply ships, Koolinda and Koolama, had sailed between Fremantle and Derby servicing all the larger coastal towns en route. Juluru, by all accounts, had conflated historically separated events into a single time frame by condensing the much earlier sequence of events around the sinking of the state ship with those occurring during the World War II Japanese bombings of Broome, Wyndham and Kalumburu (Glowczewski 2002: 273). A number of other ceremonies had inducted the World War II imagery into traditional ritual forms, and in one of these the two main protagonists were named 'Hitler' and 'German' (Kolig 1989: 120-2; Widlock 1992; Glowczewski 1983).

I have recorded a number of songs deriving from composers' shamanic dreams of thematically related events. In one of these, the dalabon jurnba ('telephone jurnba'), the composer is a psychopomp who had received in dreams a series of urgent telegraph messages from the MV Koolama as it was being attacked and ultimately sunk midway between Kalumburu and Wyndham by Japanese planes. My narrator framed the composer's dream of telegraph transmissions within the local idiom of lunggun, the involuntary bodily 'signals' (sometimes explicitly glossed as 'telegraph') that are produced in a person's body by muscle twitchings, which act as presentiments of close kindred experiencing serious trouble:

\section{Wey lejingara}

Dalabon dalabon banga

Birrinye Kalumburu jila ${ }^{10}$

9 Launched in Glasgow in October 1908, the SS Koombana was operated by the Adelaide Steamship Company. It was the first ship built exclusively for passengers and cargo for service along the West Australian coast. Sailing from Fremantle, the ship made frequent visits to ports in the state's north-west from 1909 to 1912. Named after one of the pioneering Forrest family's properties near Bunbury, the word koombana is Noongar and reputed to mean calm and peaceful. Its last voyage from Port Hedland to Broome on 20 March 1912 was, however, disastrous. The ship, plus all crew and passengers, was lost in a tropical cyclone, never to be found, except for a small amount of wreckage found at sea near Bedout Island. The loss of the SS Koombana in 1912 caused much grief and anxiety in Western Australia, not least because of the loss of 150 lives. It has been said that the loss of the Koombana was a major impetus for the early development of the State Shipping Service, which was to dominate the north-west coastal shipping trade until the end of the twentieth century.

10 Anthony Redmond, fieldnotes, June 2007. 
The man with whom I recorded this song is a Kija man who first heard it sung in Kija country at Bedford Downs Station in the eastern Kimberley (where an infamous massacre of his people had taken place in 1924). A recognisably similar version of this same song was recorded by R. M. Berndt in Halls Creek in 1962:

[D]alibun-dalibunba waiilidji barimrmbun, ngairabumana

At salt water wireless boat

galambaru djil agumanu

Kalumburu boat. By the salt water,

(That) wireless boat at Kalumburu. (Berndt 1975: 134)

This man told me this dalabon jurnba evoked violent events in which 'lot of black people been killed at Kalumburu by gardiya [whites]'. Again, we are presented with a condensation of separate spatiotemporal events into a single song and time frame, taking one cue from the Japanese air raid on the Drysdale River Mission Station in 1943 but then enfolding the song into the traumatic reach of a set of songs that commemorate the massacre of Kija people at Bedford Downs some two decades previously. ${ }^{11}$

Throughout this range of performances, there is a recurrent thematic thread of Aborigines obtaining secret knowledge of (and sometimes ritual complicity in) the sinking of those ships-a knowledge denied to whites because they are seen to lack the capacity to hear the messages emanating directly from the realm of the dead.

It should not be forgotten here that the state ships memorialised in these songs were used to transport not just the materials of everyday European power, and subsequently the ceremonial boards collected by Lommel and Petri, but also the Kimberley Aboriginal prisoners to the state jails

11 'The men had been convicted by a local court of killing a bullock on Bedford Downs Station, and were sent back to the station with "tickets" hung around their necks as a sign to the station owner that they were guilty. Some of the men discarded these tickets before they got back, but others chose to keep them. On their return, those who still had their tickets were taken to a remote location and told to chop wood. After a morning's work, the men were given a meal and told to eat quickly-the food was heavily poisoned with strychnine and all those who ate it died painful deaths. Their bodies were then burned with the wood they had chopped that morning. Two men, however, had refused to eat and made their escape. These two, along with two women who had followed the party and also witnessed the killings, returned to tell the story to their people. Passed down through the generations both as oral narrative and in the form of a joonba, Timms relates the story of the Bedford Downs massacre, in visual form, to record this tragic event both for the Gija people and wider audiences. The joonba was recently staged as the performance "Fire Fire Burning Bright" at the Melbourne and Perth Festivals (Kjellgren 2004)’ (Redmond, fieldnotes, June 2007). 
of Fremantle and Rottnest Island in the south of Western Australia. These prisoners included the mixed-race children 'removed' to state institutions such as Moore River Settlement. ${ }^{12}$

In some of these songs, the sinking of the ships is attributed to the agency of local Aboriginal barnman (or 'wish-doctors') exacting vengeance in the context of localised feuds. The dulugun jurnba of the late Bruce Niltji, composed in the late 1970s, for instance, invokes the sinking of an 'old time one' ship off the west Kimberley coast during a massive storm whipped up by a 'doctor-man' who had invoked two destructive Wunggurr (Rainbow Serpent) snakes to sink the ship-purportedly to punish Aboriginal miscreants on board.

The strong association made by local people between European military technologies such as planes and the dangerous power of Wunggurr was further evident in a number of the dreams Patrick Pentony collected from people living at Munja during the Frobenius Expedition's 1938 visit:

An aeroplane came out of the sky and landed on the ground. A mob of blacks came around and looked at the aeroplane. They were very frightened. I was very frightened. Then I awoke. Comment: This is a miriru dream. The aeroplane is Ungud. It is bad to dream of Ungud like that, for it means that he is going to kill someone. (Pentony 1938)

Pentony recorded a number of dreams in which a whitefella protagonist is either paired with or a mask for an Indigenous aggressor:

I saw a rifle lying on the ground. Then I picked up the rifle and put it inside a house. A white man whom I did not know was talking to me. Then I went back to camp. I awoke. [Dreamer's] Comment: The policeman will come today. The rifle belongs to the white man. A blackfellow will come in too, because there was a white man in the dream. This blackfellow will be the tracker. (Pentony 1938)

In another dream, a man told Pentony that 'when one sees a strange blackfellow in a dream it means a white man will come according to Janba law' (Pentony 1938).

12 Tellingly, one of the passengers aboard the Koombana when it sank was the Derby police chief, 'Corporal Frank Buttle, who had been in charge of the Derby police for about three years. He had been returning from a holiday in Perth.' 
An abiding local interest in harnessing, channelling and challenging the power of European technologies is also evident in the local Aboriginal incorporation of the dramatic power of cinema newsreels-the first harbinger of the local impacts of the looming military confrontations that would hit the region. The composer with whom Lommel worked in 1938, Alan Balbungu, had heard from various friends and countrymen working on the luggers sailing into Broome from Munja and Kunmunya for station and mission supplies about cinema's dream-like visual montages (Lommel 1996).

These films and newsreels were screened at Broome's Sun Pictures-the world's first 'picture garden'-built in 1916 by the Yamazaki pearling family, who had modernised a performance space where traditional Japanese Noh theatre had previously been staged. ${ }^{13}$ Aboriginal people were permitted entry to a racially segregated area in the very front rows, and behind them were seated the Malay and Koepanger lugger crews. Overlooking those seated at the front was a set of cushioned cane chairs reserved for the Europeans in the centre of the floor, ${ }^{14}$ and seated immediately behind them were the Japanese and then the Chinese.

The Sino-Japanese war had particularly strong local repercussions in Broome, which hosted very large Japanese and Chinese communities, ${ }^{15}$ and Balbungu's integration of images of this war into his corroboree speaks to the composer's fascination with those cinematic images of military power and violent conflict.

13 'The Sun Pictures building in Broome's Chinatown was constructed at the turn of the century on a site owned by the Yamasaki family. Initially the spacious double-fronted tin structure served as an Asian emporium selling imported Asian foodstuffs, clothing and other household goods to Broome's polyglot community. The Yamasaki building was the most commodious store in Carnarvon Street, an area ... [with] shops, bazaars, brothels, food stalls, in the Asian quarter known as Chinatown. The Yamasaki family's love affair with theatre however, saw them devote a portion of the building to a Japanese playhouse where traditional Noh theatre was performed.' See: broomemovies.com.au/ history.html.

14 This situation resembles David Stout's ethnographic descriptions of racial divisions in colonial Panama, which Taussig (1993: 144) cites as evidence that 'the cultural politics of alterity should be seen as composed not simply of one-on-one, for instance Americans and Cunas, but as a hierarchy of alterities within a colonial mosaic of attractions and repulsions'.

15 Later, after the bombing of Pearl Harbor, Broome's Japanese residents were placed in internment camps or discretely left Australia. 
Lommel described how Balbungu's garlgudada corroboree contained a number of verses evoking the yalanganna jolja ('soldiers from across the sea') in which a battle is being fought between members of the two north Kimberley patrimoieties, but employing imagery adopted from the newsreels showing scenes from the 1937 Sino-Japanese war:

It shows two rows of spirits parading towards each other, as in battle and armed with rifles. The inspiration for this song has been taken by the poet (the Worrorra man, Balbungu) from a lively account of a friend who had seen a newsreel from the Chinese-Japanese War in the cinema in Broome. In the song it is described how during the battle, the spirits burst the mountains apart and blast the rocks to pieces—an idea of exploding grenades.

Paddy Neowarra described to me how one in another variant of this dance scene:

Spotted Night Jar moiety spirit-people, Wodoy, came out in a vision of light as Jelarimirri continued to sing. A great light fell upon the ground. All the Wodoy ['spotted night jar'] people, were lit up as he sang. The composer was now singing only about this man connected with the devilstring - the 'death-cord' [human hair from deceased men plaited into a rope by widows and intimately associated with death ceremonies].

That death-cord is laid out. Then that Brolga comes marching on in the afternoon time, dancing, pushing their beaks along the ground. Then one of them, she came to the death-cord laid across to divide Wodoy on one side from Jun.gun on the other. They were pulling on the cord from either end, pulling and pulling. A boughs screen of green was set up (so that the two different mobs were hanging on to the cord from either side and one end of the cord was attached to the singer). (Lommel 1996: 62)

It is said that this string-also used to construct waranggi ('string crossdance emblems')—was originally made by jilinya, dangerous spiritwomen who live an autonomous life in the paperbark swamps, feeding themselves by hunting game such as men and choosing their own lovers. In the performances of this jurnba, two older Ngarinyin men play this role, dressing as women, weaving the string over a campfire while dancing licentiously, supposedly to attract the attention of the white soldiers to seduce them. It is said white men were first attracted to Ngarinyin country by these beautiful women at least as much as by potential pastures for their cattle. ${ }^{16}$

16 There is an interesting parallel here in Sahlins's (1985) accounts of the role Hawaiians attributed to their women performing the hula and the subsequent resentment that was generated by whites possessing their women. 
Gowanulli gave me an account of how a successful composer must visit Dulugun, the island of the dead, located off the west Kimberley coast very near to Champagny Island, where the US naval radar base had just been established. During this dream journey, the composer disappears into a trapdoor in the earth, which leads him to Dulugun, where the spirits of ancestral dead then showed him new songs over several days. When he finally awoke from his 'illness', the composer was in possession of the entire song corpus and its accompanying dances. The Ariadne's thread that the composer followed into Dulugun and back is represented in jurnba performance by a thin wire-now sometimes made of nylon fishing line-which both drags him to his destination and summons the spirits of the dead from behind their concealing bough screen. This thread, buyu, is often glossed as a 'radar' beam because of its invisible but irresistibly powerful pull.

Some of the most interesting aspects of Petri's (Petri and Petri-Odermann 1988) and Lommel's research from the Kimberley region were a product of the very close attention they had paid to the profoundly transformative historical processes unfolding before them, which were being locally articulated in new religious ceremonies, which they labelled 'travelling cults' and which were in full efflorescence during their visit.

The Kurangara cult, as Lommel saw it in 1938, was deeply saturated with symbols of European power. The principal figure, Tjanba, was said to live in a house made of corrugated iron, hunted game with a rifle rather than a spear and demanded tea, sugar and bread from his fellow ghosts. In this ceremony, the language used is Kimberley Kriol, proceedings are directed by a 'boss' and other ceremonial roles include the 'mailman', pickyba ('book-keeper') and 'police boys'. 'The symbols have changed. It is now no longer the Ungud snake but the Kurangara slab which incorporates life and death' (Lommel 1996: 28).

This figure was also associated with the spread of the then raging epidemics of leprosy and syphilis. Observing the trance states and creative shamanic illness of Balbungu, himself badly infected with leprosy, must have added considerably to Lommel's almost elegiac sense of an impending disaster looming over this particular lifeworld. 
Lommel's informants had described the Tjanba cult to him as one in which

the social order will be completely reversed: women will take the place of men; they will arrange the feasts and hand on the slabs, whereas the men will gather edible roots, without being allowed to participate in the feasts.

(Lommel 1996: 29)

The travelling 'corroborees' that made their way across the Kimberley during these pre-World War II decades ranged across the secret-sacred spectrum, from highly dangerous types such as Juluru, Dingarri and Kurangara, to the more open, public performances known as jurnba. Each of these ceremonial genres has at various times been employed by Kimberley composers and performers to articulate grappling with a range of internal and exogenous conflicts engendered and/or enhanced by the impacts of colonisation. Aboriginal ritual efficacy can be seen here as struggling to reassert itself through investing doctor-men with an enhanced creative/destructive potential through an engagement with powerful European military technologies such as radars, telegraphs and aeroplanes.

The jurnba of Balbungu and his peers subsequently travelled through the Wurnan exchange network across a wide range of Kimberley settlements and across three or four generations to date. The songs themselves and their restless movement express local articulations of intercultural historical experience, which Lommel and his companions perceptively documented during their visits to Ngarinyin country. Patrick Pentony's contribution to the research by documenting the dreamt landscape of his Kimberley Aboriginal hosts added immeasurably to this portrait of a world not in its death throes, as Lommel and Petri suspected, but certainly beset by a massive realignment of both local and exogenous power relationships.

\section{References}

Berndt, R. M. 1975. Life and death: A Lungga (Gidja) mythic corollary. In Explorations in the Anthropology of Religion, W. E. A. van Beek and J. H. Scherer (eds), pp. 122-46. The Hague: Martinus Nijhoff.

Blundell, V. and Layton, R. 1978. Marriage, myth and models of exchange in the west Kimberleys. Mankind 11: 231-45. doi.org/10.1111/ j.1835-9310.1978.tb00654.x. 
Blundell, V., Woolagoodja, D. with Members of the Mowanjum Aboriginal Community. 2005. Keeping the Wanjinas Fresh: Sam Woolagoodja and the enduring power of lalai. Fremantle, WA: Fremantle Arts Centre Press.

Collins, B. and Smale, H. 2014. Remembering the state ship lifeline to the north west. ABC Kimberley, 19 February. Available from: abc.net.au/ local/stories/2014/02/19/3948219.htm.

Crawford, I. M. 1968. The Art of the Wandjina. London: Oxford University Press.

Crawford, I. M. 2001. We Won the Victory: Aborigines and outsiders on the north-west coast of the Kimberley. Fremantle, WA: Fremantle Arts Centre Press.

Federal Court of Australia. 2001. Wanjina Wunggurr Wilinggin WAG6016/96 and WAG6015/99 [Transcript], pp. 4883-4.

Glowczewski, B. 1983. Manifestations symboliques d'une transition économique: le Juluru, culte intertribal du 'cargo' (Australie occidentale et centrale). L'Homme 23(2): 7-35. doi.org/10.3406/hom. 1983.368369 .

Glowczewski, B. 2002. Culture cult: The ritual circulation of inalienable objects and appropriation of cultural knowledge (north-west Australia). In People and Things: Social mediation in Oceania, (eds) M. J. Ballini and B. Juillerat, pp 265-88. Durham, NC: Carolina Academic Press.

Kjellgren, E. 2004. Tradition Today: Indigenous art in Australia. Sydney: Art Gallery of New South Wales.

Kolig, E. 1989. Dreamtime Politics: Religion, world view and utopian thought in Australian Aboriginal society. Berlin: Dietrich Reimer Verlag.

Lommel, A. 1952. Die Unambal, ein Stamm in Nordwest-Australien. Hamburg, Germany: Monographien zur Völkerkunde.

Lommel, A. 1996. The Unambal: A tribe in northwest Australia. Unpublished ms, Translated by F. Zanvoort. Missabotti, NSW. 
Lommel, A. and Mowaljarlai, D. 1994. Shamanism in northwest Australia. Oceania 64(4): 277-87. doi.org/10.1002/j.1834-4461.1994. tb02472.x.

Love, J. R. B. 1917. Notes on the Wororra tribe of north-western Australia. Transactions of the Royal Society of South Australia 41: 21-38.

Mowaljarlai, D. and Malnic, J. 1993. Yorro Yorro: The spirit of the Kimberleys. Broome, WA: Magabala Books.

Mowaljarlai, D. and Rumsey, A. 1992. Ngarinyin customs and country. Unpublished booklet.

Myers F. 1980. The cultural basis of politics in Pintupi life. Mankind 12(3)(June). doi.org/10.1111/j.1835-9310.1980.tb01192.x.

Pentony, P. 1938. Collection of dream texts from Ngarinyin/Wunambal and Worrorra people. Unpublished MA thesis. University of Western Australia, Perth.

Petri, H. and Petri-Odermann, G. 1988. A nativistic and millenarian movement in north-west Australia. In Aboriginal Australians and Christian Missions, (eds) D. Rose and T. Swain, pp. 391-6. Adelaide: Australian Association for the Study of Religion.

Redmond, A. and Skyring, F. 2010. Exchange and appropriation: The Wurnan economy and Aboriginal land and labour at Karunjie Station, north-western Australia. In Indigenous Participation in Australian Economies: Historical and anthropological perspectives, (ed.) I. Keen, pp. 73-90. Canberra: ANU E Press.

Rumsey, A. and Mowaljarlai, D. 1994. Report on Survey of Painting Sites in the Roe and Moran River Areas of Western Australia. Canberra: Australian Institute of Aboriginal Studies.

Sahlins, M. 1981. Historical Metaphors and Mythical Realities: Structure in the early history of the Sandwich Islands kingdom. Ann Arbor: University of Michigan Press. doi.org/10.3998/mpub.6773.

Sahlins, M. 1985. Islands of History. Chicago: University of Chicago Press.

Sahlins, M. 2005. Structural work: How microhistories become macrohistories and vice versa. Anthropological Theory 5(1): 5-30. doi.org/10.1177/1463499605050866. 
GERMAN ETHNOGRAPHY IN AUSTRALIA

Taussig, M. I. 1993. Mimesis and Alterity: A particular history of the senses. New York: Routledge.

Widlock, T. 1992. Practice, politics and ideology of the 'travelling business' in Aboriginal religion. Oceania 63(2): 114-36. doi.org/ 10.1002/j.1834-4461.1992.tb02408.x. 
This text is taken from German Ethnography in Australia, edited by Nicolas Peterson and Anna Kenny, published 2017 by ANU Press, The Australian National University, Canberra, Australia.

dx.doi.org/10.22459/GEA.09.2017.16 